\title{
The association between circulating 25- hydroxyvitamin D and cardiovascular diseases: a meta-analysis of prospective cohort studies
}

Fatemeh Gholami ${ }^{1,2}$, Ghobad Moradi ${ }^{2,3}$, Bushra Zareei ${ }^{2,4}$, Mohammad Aziz Rasouli $^{2,4^{*}}$ (D, Bahram Nikkhoo ${ }^{5}$, Daem Roshani ${ }^{2,3}$ and Ebrahim Ghaderi ${ }^{2,3}$

\begin{abstract}
Background: There is a controversy about the association between vitamin D and cardiovascular diseases (CVDs). The effect of serum 25-OH-vitD on the risk of CVDs was evaluated.

Methods: Major electronic databases including Scopus, Science Direct, and PubMed were searched. All prospective cohort studies on the relationship between vitamin D status and CVDs conducted between April 2000 and September 2017 were included, regardless language. The study participants were evaluated regardless of their age, sex, and ethnicity. The Newcastle-Ottawa Scale was used to assess the quality of the studies. Two investigators independently selected the studies and extracted the data. The designated effects were risk ratio (RR) and hazard ratio (HR). The random effects model was used to combine the results.

Results: A meta-analysis of 25 studies with 10,099 cases of CVDs was performed. In general, a decrease in the level of vitamin $D$ was associated with a higher relative risk of CVDs (incidence-mortality combined) (RR $=1.44,95 \% \mathrm{Cl}: 1.24-1.69)$. This accounts for $54 \%$ of CVDs mortality rate (RR $=1.54,95 \% \mathrm{Cl}: 1.29-1.84$ (. However, no significant relationship was observed between the vitamin $\mathrm{D}$ status and incidence of $\mathrm{CVDs}(\mathrm{RR}=1.18,95 \% \mathrm{Cl}: 1-1.39)$. In general, low serum vitamin D level increased the risk of CVD by 44\% $(R R=1.44,95 \% \mathrm{Cl}: 1.24-1.69)$. It also increased the risk of CVD mortality ( $R R=$ $1.54,95 \% \mathrm{Cl}: 1.29-1.84)$ and incidence rates ( $\mathrm{RR}=1.18,95 \% \mathrm{Cl}: 1-1.39)$.

Conclusions: The findings showed that vitamin D deficiency increases the CVDs mortality rate. Due to the limited number of studies on patients of the both genders, further research is suggested to separately evaluate the effect of vitamin D status on CVD in men and women.
\end{abstract}

Keywords: Vitamin D, Cardiovascular disease, Meta-analysis, Prospective cohort study

\section{Background}

Vitamin D may play a role in the pathogenesis of several extra-skeletal disorders involving the dermatological, cardiovascular, immune or metabolic systems [1]. In addition, low vitamin D status is associated with other conditions including osteoporotic fractures, cancer,

\footnotetext{
* Correspondence: Rasouli1010@gmail.com

${ }^{2}$ Social Determinants of Health Research Center, Research Institute for Health Development, Kurdistan University of Medical Sciences, Sanandaj, Iran

${ }^{4}$ Vice Chancellor for Educational and Research, Clinical Research

Development Unit, Kowsar Hospital, Kurdistan University of Medical Sciences, Sanandaj, Iran

Full list of author information is available at the end of the article
}

diabetes, respiratory diseases, and an increased all-cause mortality [2-10]. One of the most important issues is the effect of vitamin D deficiency on the incidence and mortality rates of cardiovascular diseases (CVDs) [11].

The CVDs are one of the top leading causes of mortality and morbidity worldwide [12]. Coronary heart disease (CHD) accounts for more than one half of the deaths in the developing countries and one-fourth of the deaths in the developed countries $[12,13]$. The CHD is the most common type of heart disease, and the annual direct and indirect medical costs associated with it exceed $\$ 100$ billion each year in the United States [14]. 
A reduced level of 25-hydroxyvitamin D (25-OH-vitD) in plasma, as an indicator of vitamin D deficiency, is associated with several risk factors of stroke, such as hypertension, thrombosis, atherosclerosis, and inflammation. A few studies have shown that the reduction in 25$\mathrm{OH}$-vitD is directly associated with an increased risk of stroke and CVDs. However, some studies have shown completely different results [15-21]. Previous metaanalysis results from Randomized Controlled Trial (RCTs) have shown that the effects of vitamin D supplementation on CVDs, the risk factors, or glycemic outcomes are controversial or null [22]. Due to a lack of consensus on the association between serum 25-OHvitD and CVDs, there is no established and clear measure for protecting against vitamin $\mathrm{D}$ deficiency and reducing the incidence and mortality of CVDs. Therefore, this study is aimed to determine the relationship between the level of 25-OH-vitD and CVDs incidence and mortality in people without underlying CVD-related conditions.

\section{Methods}

The authors are asked to provide registration information about the systematic review, (registration number: 116885).

This systematic review and Meta-analysis was performed according to the Meta-Analyses of Observational Studies in Epidemiology (MOOSE) and Preferred Reporting Items for Systematic Reviews and Meta-Analyses (PRISMA) (RRR) [23, 24]. (Fig. 1).

\section{Information sources}

Three databases were searched including PubMed (April 2000 to September 2017), Science Direct (April 2000 to September 2017), and Scopus (April 2000 to September 2017). In order to find additional references, the reference lists of all retrieved studies, especially systematic reviews were also scanned [25-31]. Furthermore theses and journals about the association of vitamin $\mathrm{D}$ and CVDs were also searched.

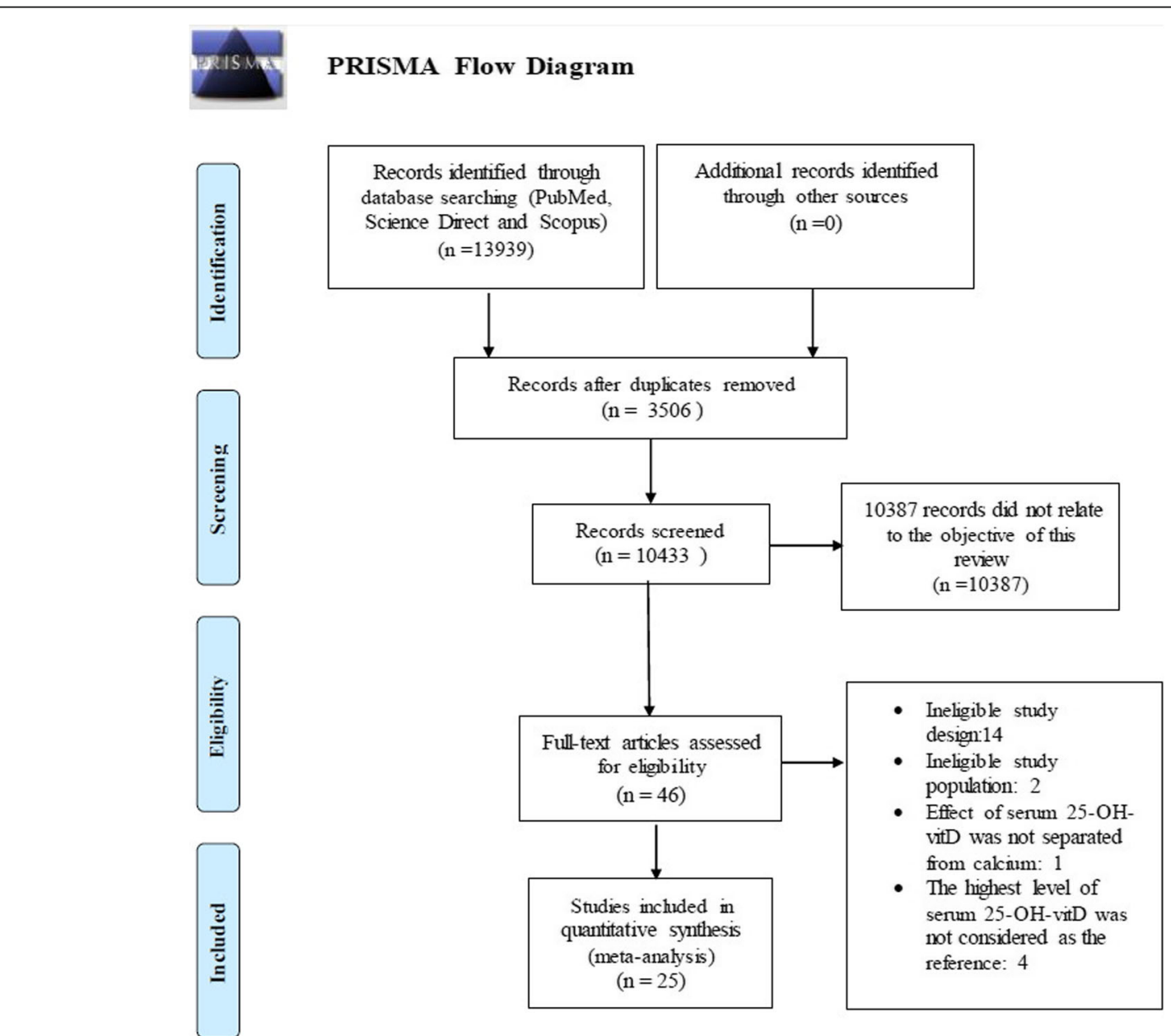

Fig. 1 Flow diagram of the study selection process. As shown our initial searches resulted in 13,939 citations. After screening title and abstracts, 46 studies were considered potentially eligible and retrieved in full text, of these 25 studies were subsequently included in the meta-analysis 


\section{Search}

Prospective cohort studies on people without underlying CVD-related conditions addressing the association between vitamin D and CVDs were included. The search strategy included a combination of the following keywords:

"vitamin D" OR "cholecalciferol" OR "25-hydroxyvitamin D” OR “25-OH-D” OR “25(OH)D” AND "cerebrovascular disease" OR "cardiovascular diseases" AND "mortality" OR "incidence" OR "survival" AND "prospective studies" OR "cohort studies" OR "longitudinal studies" OR "observational studies.”

\section{Study selection}

All prospective cohort studies that evaluated the relationship between vitamin D and CVDs were included in the study, regardless of their language. The study population consisted of healthy individuals regardless of age, gender, and ethnicity. Only studies published after 2000 were included because the methods of measuring Vitamin $\mathrm{D}$ in these studies were different from those published before 2000. The exclusion criteria were 1) studies whose baseline population had diseases like metabolic syndrome, diabetes, and CVD, or needed hemodialysis; 2) case reports, editorials, letters, meeting abstracts, or review articles; and 3) retrospective studies, crosssectional studies, or case-control studies. Exposure was defined as the level of vitamin $\mathrm{D}$, and the outcome of the study was the incidence of CVDs or mortality due to CVDs. The CVDs included in the study were stroke and CHD [WHO International Classification of Diseases (ICD)-10 I60-69; http://www.who.int/classifications/icd/ en]. In addition, cardiac arrest (I46), heart failure (I50), and sudden death (R69) were included. The CHD included acute myocardial infarction, angina pectoris, and other ischemic heart diseases (ICD- 10 I20-I25).

To ensure correct paper selection according to the inclusion criteria, two researchers (FG and MAR) conducted the selection process independently. They were not blind to the name of the authors, the journals, and the results. Any disagreement between them would be resolved by consulting with the third researcher (GM).

Full-text of the selected titles were retrieved and assessed by two authors (FG, MAR) independently to ensure adherence to selection criteria. In addition, the reference lists of the studies were searched to identify additional publications.

\section{Screening, data extraction, and quality assessment}

The primary search results were reviewed and duplicate studies were deleted. In addition, more articles were eliminated after reviewing the titles and abstracts. Finally, full text of the remaining articles was assessed for eligibility. Two researchers (FG, MAR) extracted the data from the selected studies. The extracted variables for data analysis included the name of the first author, study title, publication year, study location, participants' age at baseline, sample size, number of cases, follow-up duration, gender, study outcomes (incidence of or mortality due to CVD), levels of circulating 25-OH-vitD (values in $\mathrm{ng} / \mathrm{ml}$ multiplied by 2.496 for conversion to $\mathrm{nmol} / \mathrm{l}$ ), measurement methods (radioimmunoassay, mass spectrometry, etc.), and RR (95\% CI) for the highest vs. lowest categories of vitamin $\mathrm{D}$ and variables adjusted in the analysis. The extracted data were entered into an electronic data sheet.

The Newcastle-Ottawa Scale (NOS) was used by two independent researchers (GF and MAR) to evaluate the risk of bias and the quality of the studies [32]. This scale is based on a star system (maximum of nine stars) to evaluate a study in three domains: selection of participants, comparability of study groups, and the ascertainment of outcomes of interest. Studies that received a score of nine stars were categorized as low risk of bias (high quality), seven or eight stars as medium risk (moderate quality), and six or less as high risk of bias (low quality).

\section{Statistical analysis}

Pooled measures were calculated as the inverse varianceweighted mean of the logarithm of RR and HR with 95\% CI to assess the strength of the association. The RR (95\% CI) for the highest vs. lowest categories of vitamin $\mathrm{D}$ was used in this study.

The results were reported separately for men and women and the effect was evaluated using the random effects model. The consistency of findings across studies was assessed by standard $\chi^{2}$ tests and the $\mathrm{I}^{2}$ statistic [33]. Heterogeneity was evaluated quantitatively using $\mathrm{I}^{2}$ according to the Higgins classification in which $\mathrm{I}^{2}=25,50$, and $75 \%$ indicate low, moderate, and high heterogeneity respectively [34]. A funnel plot [35] and the Egger's test were used to evaluate publication bias [36].

Sensitivity analysis was performed with one study removed at a time [37], so that a study would be considered excessively influential if the significance of its "omitted" meta-analytic estimate differed relatively from the overall estimate. Meta-regression was used to evaluate the heterogeneity between studies [38]. The data analyses were done in Stata 12 (Stata Corp, College Station, TX) $(P<0.05)$. The authors are asked to provide registration information about the systematic review, (registration number: 116885).

\section{Results}

A total of 13,939 studies were found up to September 2017 of which 845 references were selected through checking the reference lists. Of the 10,433 retrieved references, 3506 references were excluded as duplicates, and 10,387 references were irrelevant. Out of 46 
retrieved references with full text, 25 studies were eligible for the meta-analysis.

\section{Characteristics of the reviewed studies}

This meta-analysis was performed on the 25 studies with 10,099 cases of CVDs (Table 1). The incidence rate of CVDs was evaluated in six studies [30, 41, 42, $44,47,48$ ], and the mortality rate of CVDs was evaluated in 19 studies. The serum level of 25-OH-vitD was measured using radioimmunoassay, mass spectrometry, and other methods. Radioimmunoassay was used in 10 studies [18, 19, 39, 40, 45, 50, 56, 58-60] and mass spectrometry was used in six studies [44, $46,47,49,52,54]$. The highest level of serum 25$\mathrm{OH}$-vitD was considered as the reference. In the majority of papers, the highest and lowest categories of vitamin $\mathrm{D}$ consumption were $50 \mathrm{nmol} / \mathrm{l}$ and $30 \mathrm{nmol} / \mathrm{l}$ respectively. Totally, 13 studies were conducted in the US [21, 44-51, 56, 59, 60], 11 in Europe [10, 19, 39$43,53-55,58,61]$, and one was carried out in another continent [18]. Five studies presented the results for male patients [39, 44, 47, 52, 54], two studies evaluated female patients $[18,50]$, and other studies included both male and female patients. Moreover, the quality of 18 studies was high and quality of seven studies was intermediate $[19,40,44$, $45,51,58,59]$. The follow-up period was 5 years in four studies $[40,41,47,51]$ and longer in other studies (Table 2). The data of all the reviewed studies were adjusted for age and gender.

\section{Association between circulating 25-OH-vitD levels and CVDs}

The effect of vitamin D status on CVDs was calculated using RR and the effect was considered with the greatest degree of control for the potential confounders. Here, RR (95\% CI) for the highest vs. lowest categories of vitamin D was used. In general, decreased level of vitamin D was associated with an increased relative risk of CVDs $(\mathrm{RR}=1.44$, 95\% CI: $1.24-1.69)$, accounting for $54 \%$ of CVDs mortality ( $R R=1.54$, 95\% CI: $1.29-1.84$ (. However, no significant relationship was observed between vitamin $\mathrm{D}$ status and incidence of CVDs ( $\mathrm{RR}=1.18$, 95\% CI: 1-1.39).

In general, low circulating 25-OH-vitD levels increased the risk of CVDs by $44 \%(\mathrm{RR}=1.44,95 \%$ CI: $1.24-1.69)$ (Fig. 1). Low circulating 25-OH-vitD levels increased the risk of CVDs incidence ( $R R=1.18,95 \% \mathrm{CI}: 1-1.39)$ and mortality ( $R R=1.54,95 \%$ CI: $1.29-1.84$ ) (Fig. 1). The size of the gray box was proportional to the weight assigned to each study, and the horizontal lines represent the $95 \%$ CIs. There was evidence of heterogeneity
$\left(\mathrm{I}^{2}\right)$ between the observational studies, which was equal to $84.7 \%(P<0.001)$ for CVD (Fig. 2$)$.

\section{Subgroup analysis and assessment of publication bias} There was no publication bias according to the Egger's test $(P=0.76)$. Asymmetry was observed in the funnel plot (Fig. 3), due to small-study effects [62], in a study by Pilz, Lee, and Formiga [39, 40, 61]. There was no change in the overall estimate (RR) of the study after excluding three studies. The results of the sensitivity analysis for CVDs showed that excluding none of the studies changed the overall estimate of the study significantly; this relationship was 1.44 , ranging from 1.23 to 1.68 .

A meta-regression was performed in the subgroups to detect the source of heterogeneity. The estimated effect showed no association with the outcome [CVD incidence: $\mathrm{RR}=1.18$ (95\% CI: $1-1.39$ ); CVD mortality: $\mathrm{RR}=$ 1.54 (95\% CI: $1.29-1.84)$ ] $(P=0.11)$; location [Europe: $\mathrm{RR}=1.25$ (95\% CI: 0.95-1.65); others: $\mathrm{RR}=0.68(95 \%$ CI: $0.30-1.54)$ ] $(P=0.12$ (; quality [high: $\mathrm{RR}=1.30(95 \%$ CI: 1.16-1.46); moderate: $\mathrm{RR}=1.58$ (95\% CI: 1.15-2.15)] $(P=0.26)$; gender [male: $\mathrm{RR}=1$ (95\% CI: $0.84-1.20)$; female: $\mathrm{RR}=1.12(95 \% \mathrm{CI}: 0.78-1.59)] \quad(P=0.80)$; and duration of follow-up [ $<5$ years: $R R=1.69(95 \% \mathrm{CI}$ : 1.46-1.96); > 5 years: $\mathrm{RR}=1.45$ (95\% CI: $1.22-1.73)]$ $(P=0.98)$.

Based on the studies that used mass spectrometry to measure the serum level of 25-OH-vitD ( $R R=1.08(95 \%$ CI: 0.96-1.21) and compared with the studies that used radioimmunoassay $(\mathrm{RR}=1.61$ (95\% CI: $1.23-2.11)(P=$ $0.03)$, there may be an association between serum 25$\mathrm{OH}$-vitD and an increased risk of CVD by $8 \%$.

The number of subjects $(P=0.69)$ and cases $(P=0.91)$ were not among the sources of heterogeneity (Table 2).

\section{Discussion}

The results of the meta-analysis showed a negative association between the serum 25-OH-vitD concentration and the risk of CVDs morbidity and mortality. Decreased level of vitamin D was associated with an increased relative risk of CVD ( $R R=1.44,95 \%$ CI: $1.24-$ $1.69)$, accounting for $54 \%$ of CVD mortality ( $R R=1.54$, 95\% CI: 1.29-1.84(. However, no significant relationship was observed between the vitamin $\mathrm{D}$ status and incidence of CVDs ( $R R=1.18,95 \%$ CI: $1-1.39$ ).

The results from the experimental studies have shown a positive effect of vitamin $\mathrm{D}$ on the risk factors associated with CVDs and its progression [57, 63-66].

The results from the meta-analysis revealed that the majority of the cohort studies found a significant relationship between the vitamin D status and CVD mortality rate $[26,67,68]$, which is consistent with the previous reviews. However, some studies found no linear 
Table 1 Characteristics of studies included on dairy foods and CVD

\begin{tabular}{|c|c|c|c|c|c|c|c|c|}
\hline Author & Study, continent & $\begin{array}{l}\text { Age } \\
\text { (years) }\end{array}$ & Subjects & Sex & Quality & $\begin{array}{l}\text { Follow-up } \\
\text { (years) }\end{array}$ & $\begin{array}{l}\text { Outcome } \\
\text { (cases) } \\
\text { CVD }\end{array}$ & $\begin{array}{l}\text { Method of measurement } \\
\text { (vitamin D) }\end{array}$ \\
\hline Lee, 2014 [39] & $\begin{array}{l}\text { European Male Ageing Study } \\
\text { (EMAS), Europe }\end{array}$ & 60 & 2452 & Male & High & 4.3 & 72 & Radioimmunoassay (RIA) \\
\hline Formiga, 2014 [40] & The Octabaix Study, Europe & 85 & 312 & Both & Moderate & 2.8 & 25 & Radioimmunoassay (RIA) \\
\hline Perna, 2013 [41] & ESTHER Study, Europe & $50-74$ & 7709 & Both & High & 6.5 & 1011 & $\begin{array}{l}\text { DiaSorin-Liason } \\
\text { (Diasorin, Inc) and the IDS-iSYS } \\
\text { (Immunodiagnostic Systems } \\
\text { GmbH) immunoassayes }\end{array}$ \\
\hline Kühn, 2013 [42] & $\begin{array}{l}\text { The European Investigation into } \\
\text { Cancer and Nutrition (EPIC), Europe }\end{array}$ & 50.6 & 2132 & Both & High & 7.7 & 1030 & MassChrom reagent kit \\
\hline $\begin{array}{l}\text { Scho"ttker, } 2013 \\
{[43]}\end{array}$ & ESTHER study, Europe & $50-74$ & 9578 & Both & High & 9.5 & 350 & Diasorin-Liaison analyzer \\
\hline Bajaj, 2013 [44] & $\begin{array}{l}\text { Osteoporotic Fractures in Men } \\
\text { (MrOS), } \\
\text { American }\end{array}$ & $>65$ & 2990 & Male & Moderate & 5.9 & 740 & $\begin{array}{l}\text { Liquid chromatography- } \\
\text { tandem mass spectrometry }\end{array}$ \\
\hline Liu, 2012 [45] & $\begin{array}{l}\text { Third National Health and Nutrition } \\
\text { Examination Survey (NHANESIII), } \\
\text { American }\end{array}$ & $\geq 35$ & 13,134 & Both & Moderate & 8 & 1451 & Radioimmunoassay (RIA) \\
\hline $\begin{array}{l}\text { Kritchevsky, } 2012 \\
{[46]}\end{array}$ & $\begin{array}{l}\text { the Health, Aging, and Body } \\
\text { Composition study (Health ABC) } \\
\text { study, } \\
\text { American }\end{array}$ & 74.7 & 2638 & Both & High & 8.5 & 228 & Radioimmunoassay (RIA) \\
\hline $\begin{array}{l}\text { Messenger, } 2012 \\
{[47]}\end{array}$ & $\begin{array}{l}\text { Osteoporotic Fractures in Men } \\
\text { (MrOS) Study, } \\
\text { American }\end{array}$ & 76.4 & 813 & Male & High & 4.4 & 140 & Mass spectrometry (MS) \\
\hline Welsh, 2012 [48] & $\begin{array}{l}\text { The MIDSPAN Family Study, } \\
\text { American }\end{array}$ & $30-59$ & 1522 & Both & High & 14.4 & 297 & Mass spectrometry (MS) \\
\hline $\begin{array}{l}\text { Kestenbaum, } 2011 \\
\text { [49] }\end{array}$ & $\begin{array}{l}\text { The CHS (Cardiovascular } \\
\text { Health Study), } \\
\text { American }\end{array}$ & $\geq 65$ & 2312 & Both & High & 14 & 389 & Mass spectrometry (MS) \\
\hline Eaton, 2011 [50] & $\begin{array}{l}\text { Women's Health Initiative (WHI), } \\
\text { American }\end{array}$ & $50-79$ & 2429 & Female & High & 10 & 79 & Radioimmunoassay \\
\hline $\begin{array}{l}\text { Anderson, } 2010 \\
\text { [51] }\end{array}$ & $\begin{array}{l}\text { Intermountain Heart Collaborative } \\
(\mathrm{IHC}) \text {, } \\
\text { American }\end{array}$ & 55 & 27,686 & Both & Moderate & 1.3 & 1193 & $\begin{array}{l}\text { Chemiluminescent } \\
\text { immunoassay }\end{array}$ \\
\hline Bolland, 2010 [18] & $\begin{array}{l}\text { Healthy postmenopausal women, } \\
\text { Others }\end{array}$ & 74 & 1471 & Female & High & 5 & 63 & Radioimmunoassay (RIA) \\
\hline $\begin{array}{l}\text { Cawthon, } 2010 \\
\text { [52] }\end{array}$ & $\begin{array}{l}\text { Osteoporotic Fractures in Men } \\
\text { (MrOS) study, } \\
\text { American }\end{array}$ & $\geq 65$ & 1594 & Male & High & 7.3 & 110 & Mass spectrometry (MS) \\
\hline Virtanen, 2010 [53] & $\begin{array}{l}\text { The KIHD study, } \\
\text { Europe }\end{array}$ & $53-73$ & 1136 & Both & High & 9.1 & 35 & $\begin{array}{l}\text { An HPLC using diode array } \\
\text { detector }\end{array}$ \\
\hline $\begin{array}{l}\text { Michae"Isson, } \\
2010[54]\end{array}$ & $\begin{array}{l}\text { The Uppsala Longitudinal Study of } \\
\text { Adult Men (ULSAM), } \\
\text { Europe }\end{array}$ & 71 & 1194 & Male & High & 12.7 & 196 & Mass spectrometry (MS) \\
\hline Jassal, 2010 [21] & $\begin{array}{l}\text { The Rancho Bernardo Study, } \\
\text { American }\end{array}$ & 76 & 1073 & Both & High & 6.8 & 111 & $\begin{array}{l}\text { Competitive binding protein } \\
\text { recognition and } \\
\text { chemiluminescence detection }\end{array}$ \\
\hline $\begin{array}{l}\text { Hutchinson, } 2010 \\
\text { [55] }\end{array}$ & the fourth Tromsø study, Europe & 58.9 & 7161 & Both & High & 11.7 & 325 & $\begin{array}{l}\text { Immunometry (ECLIA) using } \\
\text { an automated } \\
\text { clinical chemistry analyzer }\end{array}$ \\
\hline Ginde, 2009 [56] & $\begin{array}{l}\text { National Center for Health Statistics } \\
\text { conducted the Third National } \\
\text { Health and Nutrition } \\
\text { Examination Survey (NHANES III), } \\
\text { American }\end{array}$ & $\geq 65$ & 3408 & Both & High & 7.3 & 767 & Radioimmunoassay (RIA) \\
\hline
\end{tabular}


Table 1 Characteristics of studies included on dairy foods and CVD (Continued)

\begin{tabular}{|c|c|c|c|c|c|c|c|c|}
\hline Author & Study, continent & $\begin{array}{l}\text { Age } \\
\text { (years) }\end{array}$ & Subjects & Sex & Quality & $\begin{array}{l}\text { Follow-up } \\
\text { (years) }\end{array}$ & $\begin{array}{l}\text { Outcome } \\
\text { (cases) } \\
\text { CVD }\end{array}$ & $\begin{array}{l}\text { Method of measurement } \\
\text { (vitamin D) }\end{array}$ \\
\hline Pilz, 2009 [57] & The Hoorn Study Europe & $50-75$ & 614 & Both & High & 6.2 & 20 & $\begin{array}{l}\text { Means of a competitive } \\
\text { binding protein assay }\end{array}$ \\
\hline Semba, 2009 [58] & $\begin{array}{l}\text { Invecchiare in Chianti, } \\
\text { "Aging in the Chianti Area" } \\
\text { (InCHIANTI) study, Europe }\end{array}$ & $\geq 65$ & 1006 & Both & Moderate & 6.5 & 107 & Radioimmunoassay (RIA) \\
\hline Dobnig, 2008 [19] & $\begin{array}{l}\text { The Ludwigshafen Risk and } \\
\text { Cardiovascular Health (LURIC) } \\
\text { study, Europe }\end{array}$ & 62 & 737 & Both & Moderate & 7.7 & 463 & Radioimmunoassay (RIA) \\
\hline $\begin{array}{l}\text { Melamed, } 2008 \\
\text { [59] }\end{array}$ & $\begin{array}{l}\text { Third NationalHealth and } \\
\text { Nutrition Examination } \\
\text { Survey (NHANESIII), } \\
\text { American }\end{array}$ & $\geq 20$ & 1331 & Both & Moderate & 8.7 & 777 & Radioimmunoassay (RIA) \\
\hline Wang, 2008 [60] & $\begin{array}{l}\text { The Framingham Offspring } \\
\text { cohort, American }\end{array}$ & 59 & 1739 & Both & High & 5.4 & 120 & Radioimmunoassay (RIA) \\
\hline
\end{tabular}

Table 2 Summary risk estimates of the association between vitamin D and risk of CVD

\begin{tabular}{|c|c|c|c|c|c|c|}
\hline & \multirow[t]{2}{*}{$N^{b}$} & \multirow{2}{*}{$\begin{array}{l}\text { Number } \\
\text { of cases }\end{array}$} & \multirow{2}{*}{$\begin{array}{l}\text { Risk estimate }(95 \% \mathrm{Cl}) \\
\text { REM }\end{array}$} & \multicolumn{3}{|c|}{ Heterogeneity test } \\
\hline & & & & $\overline{1^{2}(\%)}$ & $P$ & $\mathrm{P}^{\mathrm{a}}$ \\
\hline Vitamin D & 25 & 10,099 & $1.44(1.24-1.69)$ & 84.7 & 0.00 & \\
\hline Outcome & & & & & & 0.11 \\
\hline Incidence $[32,41,42,44,47,60]$ & 6 & 3338 & $1.18(1-1.39)$ & 57.7 & 0.03 & \\
\hline Mortality $[18,19,21,39,40,43,45,46,49-59]$ & 19 & 6761 & $1.54(1.29-1.84)$ & 81.4 & 0.00 & \\
\hline \multicolumn{7}{|l|}{ Location where the study was conducted } \\
\hline American $[21,44-52,56,59,60]$ & 13 & 6402 & $1.31(1.12-1.54)$ & 73.8 & 0.00 & 1 \\
\hline Europe $[19,39-43,53-55,57,58]$ & 11 & 3634 & $1.67(1.27-2.19)$ & 85.6 & 0.00 & 0.09 \\
\hline Others [18] & 1 & 63 & $0.90(0.50-1.61)$ & - & - & - \\
\hline Sex & & & & & & 0.80 \\
\hline Male $[39,44,47,52,54]$ & 5 & 1258 & $1(0.84-1.20)$ & 0.00 & 0.54 & \\
\hline Female $[18,50]$ & 2 & 142 & $1.12(0.78-1.59)$ & 0.00 & 0.35 & \\
\hline Quality & & & & & & 0.26 \\
\hline High $[18,21,39,41-43,46-50,52-57,60]$ & 18 & 5343 & $1.30(1.16-1.46)$ & 38.8 & 0.04 & \\
\hline Moderate $[19,40,44,45,51,58,59]$ & 7 & 4756 & $1.58(1.15-2.15)$ & 92.7 & 0.00 & \\
\hline \multicolumn{7}{|l|}{ Measurement of vitamin D } \\
\hline Radioimmunoassay $[18,19,39,40,45,50,56,58-60]$ & 10 & 3924 & $1.61(1.23-2.11)$ & 82.3 & 0.00 & 1 \\
\hline Mass spectrometry $[44,46,47,49,52,54]$ & 7 & 2100 & $1.08(0.96-1.21)$ & 8.3 & 0.36 & 0.03 \\
\hline Others $[21,41-43,51,53,55,57]$ & 8 & 6024 & $1.45(1.21-1.74)$ & 72.1 & 0.00 & 0.39 \\
\hline Duration of follow up & & & & & & 0.98 \\
\hline$<5$ years $[39,40,47,51]$ & 4 & 1430 & $1.69(1.46-1.96)$ & 0.00 & 0.39 & \\
\hline$>5$ years $[18,19,21,41-46,48-50,52-60]$ & 21 & 8669 & $1.45(1.22-1.73)$ & 86.7 & 0.00 & \\
\hline
\end{tabular}

REM random effect model

a Pvalue for metaregression, and location where the study was conducted (American as the reference) and Measurement of vitamin D (Radioimmunoassay as the reference)

${ }^{\mathrm{b}} \mathrm{N}$ : number of results 


\begin{tabular}{|c|c|c|c|}
\hline Author & year & $\operatorname{sex}$ & $\begin{array}{l}\% \\
\text { Weight }\end{array}$ \\
\hline \multicolumn{3}{|l|}{ mortality } & \\
\hline Lee & 2014 & Male & $1.26(0.41,3.83) \quad 1.47$ \\
\hline Formiga & 2014 & Both & 1.41 \\
\hline Scho ttker & 2013 & Both & 4.75 \\
\hline Liu & 2012 & Both & 5.53 \\
\hline Kritchevsky & 2012 & Both & 2.81 \\
\hline Kestenbaum & 2011 & Both & 4.54 \\
\hline Eaton & 2011 & Female & 3.95 \\
\hline Jassal & 2010 & Both & 5.28 \\
\hline Hutchinson & 2010 & Both & 5.33 \\
\hline Michae Isson & 2010 & Male & 2.62 \\
\hline Virtanen & 2010 & Both & 3.09 \\
\hline Bolland & 2010 & Female & 3.23 \\
\hline Cawthon & 2010 & Male & 3.11 \\
\hline Anderson & 2010 & Both & 5.55 \\
\hline Semba & 2009 & Both & 5.65 \\
\hline Pilz & 2009 & Both & 1.72 \\
\hline Ginde & 2009 & Both & 2.68 \\
\hline Dobnig & 2008 & Both & 4.57 \\
\hline Melamed & 2008 & Both & 4.73 \\
\hline \multicolumn{3}{|c|}{ Subtotal $(\mathrm{l}$-squared $=81.4 \%, p=0.000)$} & 72.02 \\
\hline \multirow{2}{*}{\multicolumn{3}{|c|}{ incidence }} & \\
\hline & & \\
\hline Perna & 2013 & Both & 5.40 \\
\hline Kühn & 2013 & Both & 4.76 \\
\hline Bajaj & 2013 & Male & 5.28 \\
\hline Messenger & 2012 & Male & 3.45 \\
\hline Welsh & 2012 & Both & 5.64 \\
\hline Wang & 2008 & Both & 3.46 \\
\hline \multicolumn{3}{|c|}{ Subtotal $(1-$ squared $=57.7 \%, p=0.037)$} & 27.98 \\
\hline \multicolumn{3}{|c|}{ Overall $(1-$ squared $=84.7 \%, p=0.000)$} & 100.00 \\
\hline \multicolumn{3}{|c|}{ NOTE: Weights are from random effects analysis } & \\
\hline & & $\pi$ & \\
\hline
\end{tabular}

Fig. 2 The association of vitamin D with total cardiovascular diseases events, cardiovascular diseases incidence and cardiovascular diseases mortality. The size of gray box is positively proportional to the weight assigned to each study, and horizontal lines represent the $95 \%$ confidence intervals

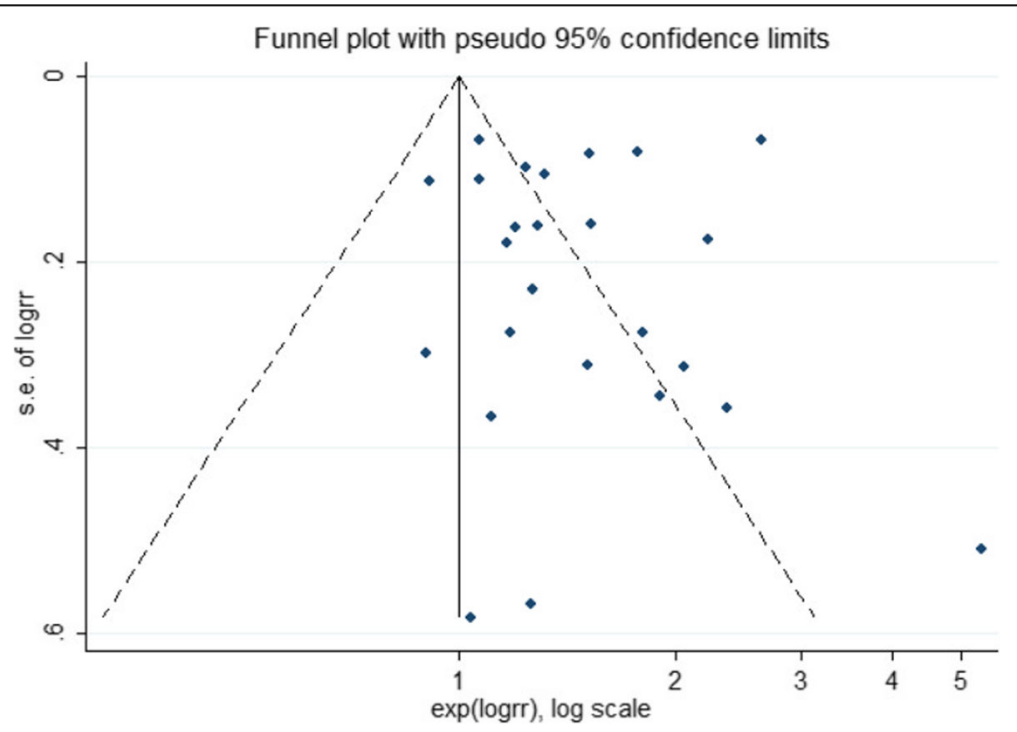

Fig. 3 Funnel plot for the analysis of vitamin D and cardiovascular diseases 
relationship between the vitamin D status and the risk of CVDs $[59,60]$. Moreover, the results from the cohort studies revealed that the patients who received more than $75-87.5 \mathrm{nmol} / \mathrm{l}$ of $25-\mathrm{OH}$-vitD were more likely to die due to CVDs [69], which may be due to the limited number of studies included in the meta-analysis as well as the application of different levels of vitamin D and adjustment for confounding variables.

\section{Advantages and limitations}

Two main advantages of the present review are the high quality of the reviewed studies and adjustment of the confounding variables such as age, body mass index, and physical activity of the participants. The initial results of the RCTs demonstrated that an increased in daily consumption of vitamin D reduced CVDs mortality [70], and increased vitamin $\mathrm{D}$ intake prevented stroke and CVDs [68, 71, 72]. However, it should be noted that there is the possibility of residual confounding in observational studies. Most of the previous and ongoing RCTs have shown that vitamin D supplementation has no impact on CVD surrogate markers in reasonably healthy people [22]. Further evidences by Mendelian randomization trials also did not show any causality of genetically reduced $25(\mathrm{OH}) \mathrm{D}$ concentrations and myocardial infarction, ischemic heart disease, or coronary artery disease [73, 74].

This study also has potential limitations like the fact that only prospective cohort studies conducted in less than the last 10 years were reviewed. In addition, the dose-response effect of vitamin $\mathrm{D}$ on the incidence and mortality rate of CVDs was not evaluated. This metaanalysis compared the highest and lowest levels of vitamin $\mathrm{D}$ and revealed that the highest concentration of vitamin $\mathrm{D}$ was associated with increased CVD mortality rates. The heterogeneity in our meta-analysis is partly due to the application of various methods to measure the serum levels of vitamin D. As such, heterogeneity was more significant in studies that used mass spectrometry compared with studies that used radioimmunoassay to measure the serum level of $25-\mathrm{OH}$-vitD. So that, radioimmunoassay was used as a measure and the other methods were compared to it. Thus, measurement methods not only account for the heterogeneity in the studies but also indicate the important role of measurement tools in epidemiological research.

The findings showed that gender was not a significant factor, which is not supported by previous studies. As such, some studies revealed that vitamin D deficiency was associated with higher CVDs mortality rates in men, whereas in some studies, vitamin D deficiency was associated with higher CVDs mortality rates among female patients. The NHANES III showed that the CVDs mortality was higher among male patients $(\mathrm{IRR}=2.38$,
95\%CI: 1.92-2.96) [75], whereas the Gind study showed the protective role of vitamin $\mathrm{D}$ deficiency in female patients $(\mathrm{HR}=0.70,95 \% \mathrm{CI}: 0.57-0.86)$ [56]. Additionally, Brondumn revealed a higher risk of stroke in female patients $(\mathrm{HR}=1.67,95 \% \mathrm{CI}: 1.30-2.13)$ [76], which may be due to the limited number of reviewed studies focusing on gender.

The highest category of serum 25-OH-vitD was considered as the reference - i.e. $50 \mathrm{nmol} / \mathrm{l}$ in most studies. A majority of the studies reported the adequate level of serum $25-\mathrm{OH}$-vitD as $>50 \mathrm{nmol} / \mathrm{l}$ whereas some studies reported this level as $>70 \mathrm{nmol} / \mathrm{l}$ [77-79]. In addition, Bischoff-Ferrari reported the adequate level of serum 25$\mathrm{OH}$-vitD as 90-100 nmol/l throughout the world [80].

The serum levels of vitamin D vary from 25 to 75 $\mathrm{nmol} / \mathrm{l}$ in different continents; the serum level was reported as $25 \mathrm{nmol} / \mathrm{l}$ in Asia and the Middle East [81] and $40 \mathrm{nmol} / \mathrm{l}$ in African-Americans [82].

The Workshop Consensus for Vitamin D Nutritional Guidelines 3 estimated that about 50 and $60 \%$ of the older populations in North America and the rest of the world respectively do not have a satisfactory vitamin D status. The consensus further concluded that the situation is similar in younger subjects [83]. Khaw stated that after adjustment for confounding variables, the CVDs mortality rate was lower (11\%) in patients with a $25-\mathrm{OH}$-vitD level of $90 \mathrm{nmol} / \mathrm{l}$ than in patients with a 25-OH-vitD level of $30 \mathrm{nmol} / \mathrm{l}$.

Although, there is no clear information on the relationship between serum 25-OH-vitD and life expectancy, experimental studies have shown that vitamin $\mathrm{D}$ receptor-knockout mice develop metabolic defects and cardiovascular disorders [84-86]. The present study showed a strong relationship between the follow-up period (longer than five years) and the effect of serum 25-OH-vitD on CVD in cohort studies, which may be due to the varying serum 25-OH-vitD over the long periods, especially in the elderly [68].

Results from a meta-analysis of RCTs also revealed that vitamin $\mathrm{D}$ intake was associated with decreased CVDs mortality rate among the elderly; daily vitamin $\mathrm{D}$ consumption of 10-20 mg decreased the CVD mortality by $80 \%$ [87]. There are still controversies regarding the effect of vitamin D on the reduction of CVD mortality and other illnesses among the meta-analyses of RCT studies [70, 81, 88-91]. Moreover, serum 25-OH-vitD was shown to have a biphasic effect on CVDs, as both increased or decreased serum 25-OH-vitD increased the incidence of CVD [68].

It was not possible to calculate the crude effect because the required data were not available, and the analysis was performed on adjusted effects. Therefore, there is the possibility of residual confounding. However, considering the relatively high-quality data obtained 
from the studies, the analysis was performed in different subgroups separately.

\section{Conclusion}

This is the first study of its kind that evaluated the relationship between serum 25-OH-vitD status and CVDs using meta-analysis method in the recent years. The findings showed that vitamin D deficiency increased the CVD mortality. Due to the limited number of studies which included patients of both genders, further research is suggested to separately evaluate the effect of vitamin D status on CVDs among men and women.

\section{Abbreviations}

CHD: Coronary heart disease; CVDs: Cardiovascular diseases; HR: Hazard ratio; RCT: Randomized controlled trial; REM: Random effect model; RIA: Radioimmunoassay; RR: Risk ratio

\section{Acknowledgments}

The authors thank collaboration the Clinical Research Development Center, Kowsar Hospital, Sanandaj, Iran.

\section{Authors' contributions}

MAR, FG and GM designed the research. FG, MAR, GM, DR, and BZ participated in the design of the study and performed the statistical analysis. MAR, FG, GM, DR and BZ wrote the paper; MAR, FG, GM, BN, and EG edited the manuscript and assisted in the interpretation of the data and participated in its design and coordination and helped to draft the manuscript. All authors read and approved the final manuscript.

\section{Funding}

The study was sponsored by the Deputy of Research and Technology of Kurdistan University of Medical Sciences, Sanandaj, Iran (No: 94.17-94.02.13). The funding body played no role in the design of the study, collection, analysis, or interpretation of data or in writing the manuscript.

\section{Availability of data and materials}

The datasets used and/or analysed during the current study are available from the corresponding author on reasonable request.

\section{Ethics approval and consent to participate}

Not applicable.

\section{Consent for publication}

Not applicable.

\section{Competing interests}

The authors declare that they have no competing interests.

\begin{abstract}
Author details
'Department of Epidemiology, School of Public Health, Iran University of Medical Sciences, Tehran, Iran. ${ }^{2}$ Social Determinants of Health Research Center, Research Institute for Health Development, Kurdistan University of Medical Sciences, Sanandaj, Iran. ${ }^{3}$ Department of Epidemiology and Biostatistics, Faculty of Medicine, Kurdistan University of Medical Sciences, Sanandaj, Iran. ${ }^{4}$ Vice Chancellor for Educational and Research, Clinical Research Development Unit, Kowsar Hospital, Kurdistan University of Medical Sciences, Sanandaj, Iran. ${ }^{5}$ Department of Pathology, Faculty of Medicine, Kurdistan University of Medical Sciences, Sanandaj, Iran.
\end{abstract}

Received: 23 March 2019 Accepted: 24 October 2019

Published online: 07 November 2019

\section{References}

1. Giustina A, Adler RA, Binkley N, Bouillon R, Ebeling PR, Lazaretti-Castro M, et al. Controversies in Vitamin D: Summary Statement From an International Conference. The Journal of clinical endocrinology and metabolism. 2019; 104(2):234-40
2. Bjelakovic G, Gluud LL, Nikolova D, Whitfield K, Wetterslev J, Simonetti RG, et al. Vitamin D supplementation for prevention of mortality in adults. The Cochrane database of systematic reviews. 2014(1):Cd007470. https://doi.org/ 10.1002/14651858.CD007470.pub3.

3. Autier P, Boniol M, Pizot C, Mullie P. Vitamin D status and ill health: a systematic review. Lancet Diabetes Endocrinol. 2014;2(1):76-89.

4. Bischoff-Ferrari HA, Willett WC, Orav EJ, Lips P, Meunier PJ, Lyons RA, et al. A pooled analysis of vitamin $\mathrm{D}$ dose requirements for fracture prevention. $\mathrm{N}$ Engl J Med. 2012;367(1):40-9.

5. de Boer $H_{\text {, Levin }}$, Robinson-Cohen C, Biggs ML, Hoofnagle AN, Siscovick DS, et al. Serum 25-hydroxyvitamin D concentration and risk for major clinical disease events in a community-based population of older adultsa cohort study. Ann Intern Med. 2012;156(9):627-34.

6. Forouhi N, Ye Z, Rickard A, Khaw K, Luben R, Langenberg C, et al. Circulating 25hydroxyvitamin $\mathrm{D}$ concentration and the risk of type 2 diabetes: results from the European prospective investigation into Cancer (EPIC)-Norfolk cohort and updated meta-analysis of prospective studies. Diabetologia. 2012;55(8):2173-82.

7. Garland CF, Gorham ED, Mohr SB, Garland FC. Vitamin D for cancer prevention: global perspective. Ann Epidemiol. 2009;19(7):468-83.

8. Pludowski P, Holick MF, Pilz S, Wagner CL, Hollis BW, Grant WB, et al. Vitamin D effects on musculoskeletal health, immunity, autoimmunity, cardiovascular disease, cancer, fertility, pregnancy, dementia and mortality - a review of recent evidence. Autoimmun Rev. 2013;12(10):976C89.

9. Khaw KT, Luben R, Wareham N. Serum 25-hydroxyvitamin D, mortality, and incident cardiovascular disease, respiratory disease, cancers, and fractures: a 13-y prospective population study. The American journal of clinical nutrition. 2014;100(5):1361-70.

10. Schöttker B, Ball D, Gellert C, Brenner H. Serum 25-hydroxyvitamin D levels and overall mortality. A systematic review and meta-analysis of prospective cohort studies. Ageing Res Rev. 2013;12(2):708-18.

11. Karakas M, Thorand B, Zierer A, Huth C, Meisinger C, Roden M, et al. Low levels of serum 25-hydroxyvitamin $D$ are associated with increased risk of myocardial infarction, especially in women: results from the MONICA/KORA Augsburg case-cohort study. J Clin Endocrinol Metab. 2013;98(1):272-80.

12. Alwan A. Global status report on noncommunicable diseases 2010. World Health Organ:2011.

13. Mendis S, Puska P, Norrving B. Global atlas on cardiovascular disease prevention and control: World Health Organization; 2011.

14. Heidenreich PA, Trogdon JG, Khavjou OA, Butler J, Dracup K, Ezekowitz MD, et al. Forecasting the future of cardiovascular disease in the United States. Circulation. 2011;123(8):933-44.

15. Pilz S, Tomaschitz A, Drechsler C, Zittermann A. M Dekker J, Marz W. vitamin D supplementation: a promising approach for the prevention and treatment of strokes. Curr Drug Targets. 2011;12(1):88-96.

16. Pilz S, Dobnig H, Fischer JE, Wellnitz B, Seelhorst U, Boehm BO, et al. Low vitamin $D$ levels predict stroke in patients referred to coronary angiography. Stroke. 2008;39(9):2611-3.

17. Buell J, Dawson-Hughes B, Scott T, Weiner D, Dallal G, Qui W, et al. 25Hydroxyvitamin D, dementia, and cerebrovascular pathology in elders receiving home services. Neurology. 2010;74(1):18-26.

18. Bolland MJ, Bacon CJ, Horne AM, Mason BH, Ames RW, Wang TK, et al. Vitamin D insufficiency and health outcomes over $5 \mathrm{y}$ in older women. Am J Clin Nutr. 2009;91(1):82-9.

19. Dobnig H, Pilz S, Scharnagl H, Renner W, Seelhorst U, Wellnitz B, et al. Independent association of low serum 25-hydroxyvitamin D and 1, 25dihydroxyvitamin D levels with all-cause and cardiovascular mortality. Arch Intern Med. 2008;168(12):1340-9.

20. Kilkkinen A, Knekt P, Aro A, Rissanen H, Marniemi J, Heliövaara M, et al. Vitamin D status and the risk of cardiovascular disease death. Am J Epidemiol. 2009;170(8):1032-9.

21. Jassal SK, Chonchol M, Von Muehlen D, Smits G, Barrett-Connor E. Vitamin d, parathyroid hormone, and cardiovascular mortality in older adults: the rancho Bernardo study. Am J Med. 2010;123(12):1114-20.

22. Swart KM, Lips P, Brouwer IA, Jorde R, Heymans MW, Grimnes G, et al. Effects of vitamin D supplementation on markers for cardiovascular disease and type 2 diabetes: an individual participant data metaanalysis of randomized controlled trials. Am J Clin Nutr. 2018;107(6): 1043-53.

23. Moher D, Liberati A, Tetzlaff J, Altman DG, Group P. Reprint-preferred reporting items for systematic reviews and meta-analyses: the PRISMA statement. Phys Ther. 2009;89(9):873-80. 
24. Moher D, Liberati A, Tetzlaff J, Altman DG. Preferred reporting items for systematic reviews and meta-analyses: the PRISMA statement. Ann Intern Med. 2009;151(4):264-9.

25. Carvalho LSF, Sposito AC. Vitamin D for the prevention of cardiovascular disease: are we ready for that? Atherosclerosis. 2015;241(2):729-40.

26. Sokol SI, Tsang P, Aggarwal V, Melamed ML, Srinivas V. Vitamin D status and risk of cardiovascular events: lessons learned via systematic review and meta-analysis. Cardiol Rev. 2011;19(4):192-201.

27. Pilz S, Verheyen N, Grubler MR, Tomaschitz A, Marz W. Vitamin D and cardiovascular disease prevention. Nat Rev Cardiol. 2016;13(7):404-17.

28. Mozos I, Marginean O. Links between vitamin D deficiency and cardiovascular diseases. Biomed Res Int. 2015;2015:109275.

29. Papandreou D, Hamid Z-T-N. The role of vitamin D in diabetes and cardiovascular disease: an updated review of the literature. Dis Markers. 2015;2015.

30. Wang L, Manson JE, Song Y, Sesso HD. Systematic review: vitamin D and calcium supplementation in prevention of cardiovascular events. Ann Intern Med. 2010;152(5):315.

31. Bjelakovic G, Gluud LL, Nikolova D, Whitfield K, Wetterslev J, Simonetti RG, et al. Vitamin D supplementation for prevention of mortality in adults. The Cochrane database of systematic reviews. 2011;6(7):CD007470. https://doi. org/10.1002/14651858.CD007470.pub2.

32. Wells $G$, Shea B, O'connell D, Peterson J, Welch V, Losos M, et al. The Newcastle-Ottawa Scale (NOS) for assessing the quality of nonrandomised studies in meta-analyses. oxford. asp: Ottawa Hospital Research Institute, 2014; 2015.

33. Higgins JP, Thompson SG, Deeks JJ, Altman DG. Measuring inconsistency in meta-analyses. BMJ. 2003;327(7414):557.

34. Higgins JP, Green S. Cochrane handbook for systematic reviews of interventions: john Wiley \& sons; 2011.

35. Egger M, Smith GD, Schneider M, Minder C. Bias in meta-analysis detected by a simple, graphical test. BMJ. 1997;315(7109):629-34

36. Peters JL, Sutton AJ, Jones DR, Abrams KR, Rushton L. Comparison of two methods to detect publication bias in meta-analysis. Jama. 2006;295(6):676-80.

37. Tobias A. Assessing the influence of a single study in the meta-analysis estimate. Stata Technical Bulletin. 1999;8(47):15-7.

38. Higgins J, Thompson SG. Controlling the risk of spurious findings from meta-regression. Stat Med. 2004;23(11):1663-82.

39. Lee DM, Vanderschueren D, Boonen S, O'neill TW, Pendleton N, Pye SR, et al. Association of 25-hydroxyvitamin D, 1, 25-dihydroxyvitamin D and parathyroid hormone with mortality among middle-aged and older European men. Age Ageing. 2013;43(4):528-35.

40. Formiga F, Ferrer A, Megido MJ, Boix L, Contra A, Pujol R, et al. Low serum vitamin $D$ is not associated with an increase in mortality in oldest old subjects: the Octabaix three-year follow-up study. Gerontology. 2014;60(1):10-5

41. Perna L, Schöttker B, Holleczek B, Brenner H. Serum 25-hydroxyvitamin D and incidence of fatal and nonfatal cardiovascular events: a prospective study with repeated measurements. J Clin Endocrinol Metab. 2013;98(12):4908-15.

42. Kühn T, Kaaks R, Teucher B, Hirche F, Dierkes J, Weikert C, et al. Plasma 25hydroxyvitamin $\mathrm{D}$ and its genetic determinants in relation to incident myocardial infarction and stroke in the European prospective investigation into cancer and nutrition (EPIC)-Germany study. PLoS One. 2013;8(7):e69080.

43. Schöttker B, Haug U, Schomburg L, Köhrle J, Perna L, Müller H, et al. Strong associations of 25-hydroxyvitamin D concentrations with all-cause cardiovascular, cancer, and respiratory disease mortality in a large cohort study. Am J Clin Nutr. 2013;97(4):782-93.

44. Bajaj A, Stone KL, Peters K, Parimi N, Barrett-Connor E, Bauer D, et al. Circulating vitamin $\mathrm{d}$, supplement use, and cardiovascular disease risk: the mros sleep study. J Clin Endocrinol Metab. 2014;99(9):3256-62.

45. Liu L, Chen M, Hankins SR, Nùñez AE, Watson RA, Weinstock PJ, et al. Serum 25-hydroxyvitamin D concentration and mortality from heart failure and cardiovascular disease, and premature mortality from all-cause in United States adults. Am J Cardiol. 2012;110(6):834-9.

46. Kritchevsky SB, Tooze JA, Neiberg RH, Schwartz GG, Hausman DB, Johnson MA, et al. 25-Hydroxyvitamin D, parathyroid hormone, and mortality in black and white older adults: the health ABC study. J Clin Endocrinol Metab. 2012;97(11):4156-65.

47. Messenger W, Nielson C, Li H, Beer T, Barrett-Connor E, Stone K, et al. Serum and dietary vitamin $\mathrm{D}$ and cardiovascular disease risk in elderly men: a prospective cohort study. Nutr Metab Cardiovasc Dis. 2012;22(10):856-63.
48. Welsh P, Doolin O, McConnachie A, Boulton E, McNeil G, Macdonald H, et al. Circulating 25OHD, dietary vitamin D, PTH, and calcium associations with incident cardiovascular disease and mortality: the MIDSPAN family study. J Clin Endocrinol Metab. 2012;97(12):4578-87.

49. Kestenbaum B, Katz R, De Boer I, Hoofnagle A, Sarnak MJ, Shlipak MG, et al. Vitamin D, parathyroid hormone, and cardiovascular events among older adults. J Am Coll Cardiol. 2011;58(14):1433-41.

50. Eaton CB, Young A, Allison MA, Robinson J, Martin LW, Kuller LH, et al. Prospective association of vitamin $D$ concentrations with mortality in postmenopausal women: results from the Women's Health Initiative (WHI). Am J Clin Nutr. 2011;94(6):1471-8.

51. Anderson JL, May HT, Horne BD, Bair TL, Hall NL, Carlquist JF, et al. Relation of vitamin D deficiency to cardiovascular risk factors, disease status, and incident events in a general healthcare population. Am J Cardiol. 2010; 106(7):963-8.

52. Cawthon PM, Parimi N, Barrett-Connor E, Laughlin GA, Ensrud KE, Hoffman AR, et al. Serum 25-hydroxyvitamin D, parathyroid hormone, and mortality in older men. J Clin Endocrinol Metab. 2010;95(10):4625-34.

53. Virtanen JK, Nurmi T, Voutilainen S, Mursu J, Tuomainen T-P. Association of serum 25-hydroxyvitamin D with the risk of death in a general older population in Finland. Eur J Nutr. 2011;50(5):305-12.

54. Michaëlsson K, Baron JA, Snellman G, Gedeborg R, Byberg L, Sundström J, et al. Plasma vitamin D and mortality in older men: a community-based prospective cohort study. Am J Clin Nutr. 2010;92(4):841-8.

55. Hutchinson MS, Grimnes G, Joakimsen RM, Figenschau Y, Jorde R. Low serum 25-hydroxyvitamin D levels are associated with increased all-cause mortality risk in a general population: the Tromsø study. Eur J Endocrinol. 2010:162(5):935-42.

56. Ginde AA, Scragg R, Schwartz RS, Camargo CA. Prospective study of serum 25-Hydroxyvitamin D level, cardiovascular disease mortality, and all-cause mortality in older US adults. J Am Geriatr Soc. 2009;57(9):1595-603.

57. Li YC, Qiao G, Uskokovic M, Xiang W, Zheng W, Kong J. Vitamin D: negative endocrine regulator of the renin-angiotensin system and blood pressure. J Steroid Biochem Mol Biol. 2004;89:387-92.

58. Semba RD, Houston DK, Bandinelli S, Sun K, Cherubini A, Cappola AR, et al. Relationship of 25-hydroxyvitamin D with all-cause and cardiovascular disease mortality in older community-dwelling adults. Eur J Clin Nutr. 2010; 64(2):203-9.

59. Melamed ML, Michos ED, Post W, Astor B. 25-hydroxyvitamin D levels and the risk of mortality in the general population. Arch Intern Med. 2008; 168(15):1629-37.

60. Wang TJ, Pencina MJ, Booth SL, Jacques PF, Ingelsson E, Lanier K, et al. Vitamin D deficiency and risk of cardiovascular disease. Circulation. 2008; 117(4):503-11.

61. Pilz S, Dobnig H, Nijpels G, Heine RJ, Stehouwer CD, Snijder MB, et al. Vitamin D and mortality in older men and women. Clin Endocrinol. 2009; 71(5):666-72.

62. Sterne JA, Gavaghan D, Egger M. Publication and related bias in metaanalysis: power of statistical tests and prevalence in the literature. J Clin Epidemiol. 2000;53(11):1119-29.

63. Rammos G, Tseke P, Ziakka S. Vitamin D, the renin-angiotensin system, and insulin resistance. Int Urol Nephrol. 2008;40(2):419-26.

64. Norman AW, Frankel J, Heldt AM, Grodsky GM. Vitamin D deficiency inhibits pancreatic secretion of insulin. Science. 1980;209(4458):823-5.

65. Carthy E, Yamashita W, Hsu A, Ooi BS. 1, 25-Dihydroxyvitamin D3 and rat vascular smooth muscle cell growth. Hypertension. 1989;13(6 Pt 2):954-9.

66. Deluca HF, Cantorna MT. Vitamin D: its role and uses in immunology. FASEB J. 2001;15(14):2579-85.

67. Grandi NC, Breitling LP, Brenner H. Vitamin D and cardiovascular disease: systematic review and meta-analysis of prospective studies. Prev Med. 2010; 51(3-4):228-33.

68. Wang L, Song Y, Manson JE, Pilz S, März W, Michaëlsson K, et al. Circulating 25-Hydroxy-Vitamin D and Risk of Cardiovascular Disease. Circulation: Cardiovascular Quality and Outcomes. In: CIRCOUTCOMES, vol. 112; 2012. p. 967604

69. Zittermann A, lodice S, Pilz S, Grant WB, Bagnardi V, Gandini S. Vitamin D deficiency and mortality risk in the general population: a meta-analysis of prospective cohort studies. Am J Clin Nutr. 2012;95(1):91-100.

70. Autier P, Gandini S. Vitamin D supplementation and total mortality: a metaanalysis of randomized controlled trials. Arch Intern Med. 2007;167(16):1730-7. 
71. Trivedi DP, Doll R, Khaw KT. Effect of four monthly oral vitamin D 3 (cholecalciferol) supplementation on fractures and mortality in men and women living in the community: randomised double blind controlled trial. BMJ. 2003;326(7387):469.

72. Prince RL, Austin N, Devine A, Dick IM, Bruce D, Zhu K. Effects of ergocalciferol added to calcium on the risk of falls in elderly high-risk women. Arch Intern Med. 2008;168(1):103-8.

73. Brøndum-Jacobsen P, Benn M, Afzal S, Nordestgaard BG. No evidence that genetically reduced 25 -hydroxyvitamin $D$ is associated with increased risk of ischaemic heart disease or myocardial infarction: a Mendelian randomization study. Int J Epidemiol. 2015;44(2):651-61.

74. Manousaki D, Mokry LE, Ross S, Goltzman D, Richards JB. Mendelian randomization studies do not support a role for vitamin $D$ in coronary artery disease. Circ Cardiovasc Genet. 2016;9(4):349-56.

75. Fiscella $K$, Franks $P$. Vitamin $D$, race, and cardiovascular mortality: findings from a national US sample. Ann Fam Med. 2010;8(1):11-8.

76. Brøndum-Jacobsen P, Nordestgaard BG, Schnohr P, Benn M. 25Hydroxyvitamin D and symptomatic ischemic stroke: an original study and meta-analysis. Ann Neurol. 2013;73(1):38-47.

77. Ross AC, Manson JE, Abrams SA, Aloia JF, Brannon PM, Clinton SK, et al. The 2011 report on dietary reference intakes for calcium and vitamin D from the Institute of Medicine: what clinicians need to know. J Clin Endocrinol Metab. 2011;96(1):53-8.

78. Hintzpeter B, Mensink G, Thierfelder W, Müller M, Scheidt-Nave C. Vitamin D status and health correlates among German adults. Eur J Clin Nutr. 2008; 62(9):1079-89.

79. Lips P. Which circulating level of 25 -hydroxyvitamin $D$ is appropriate? J Steroid Biochem Mol Biol. 2004;89:611-4.

80. Bischoff-Ferrari HA, Giovannucci E, Willett WC, Dietrich T, Dawson-Hughes B. Estimation of optimal serum concentrations of 25-hydroxyvitamin $D$ for multiple health outcomes. Am J Clin Nutr. 2006;84(1):18-28.

81. Bischoff-Ferrari HA. Vitamin D and fracture prevention. Rheum Dis Clin N Am. 2012;38(1):107-13.

82. Looker AC, Pfeiffer CM, Lacher DA, Schleicher RL, Picciano MF, Yetley EA. Serum 25-hydroxyvitamin D status of the US population: 1988-1994 compared with 2000-2004. Am J Clin Nutr. 2008;88(6):1519-27.

83. Norman AW, Bouillon R, Whiting SJ, Veith R, Lips P. 13th workshop consensus for vitamin D nutritional guidelines. J Steroid Biochem Mol Biol. 2007;103(3-5):204.

84. Bouillon R, Carmeliet G, Verlinden L, van Etten E, Verstuyf A, Luderer HF, et al. Vitamin $D$ and human health: lessons from vitamin $D$ receptor null mice. Endocr Rev. 2008;29(6):726-76.

85. O'Kelly J, Hisatake J, Hisatake Y, Bishop J, Norman A, Koeffler HP. Normal myelopoiesis but abnormal $\mathrm{T}$ lymphocyte responses in vitamin $\mathrm{D}$ receptor knockout mice. J Clin Invest. 2002;109(8):1091.

86. Zeitz U, Weber K, Soegiarto DW, Wolf E, Balling R, Erben RG. Impaired insulin secretory capacity in mice lacking a functional vitamin D receptor. FASEB J. 2003;17(3):509-11.

87. Arnson $Y$, Amital $H$, Shoenfeld $Y$. Vitamin $D$ and autoimmunity: new aetiological and therapeutic considerations. Ann Rheum Dis. 2007;66(9): 1137-42.

88. Chowdhury R, Kunutsor S, Vitezova A, Oliver-Williams C, Chowdhury S, Kiefte-de-Jong JC, et al. Vitamin D and risk of cause specific death: systematic review and meta-analysis of observational cohort and randomised intervention studies. BMJ. 2014;348:g1903.

89. Avenell A, MacLennan GS, Jenkinson DJ, McPherson GC, McDonald AM, Pant PR, et al. Long-term follow-up for mortality and cancer in a randomized placebo-controlled trial of vitamin D3 and/or calcium (RECORD trial). J Clin Endocrinol Metab. 2011;97(2):614-22.

90. Brunner RL, Wactawski-Wende J, Caan BJ, Cochrane BB, Chlebowski RT, Gass $M L$, et al. The effect of calcium plus vitamin D on risk for invasive cancer: results of the Women's Health Initiative (WHI) calcium plus vitamin D randomized clinical trial. Nutr Cancer. 2011;63(6):827-41.

91. Prentice R, Pettinger M, Jackson R, Wactawski-Wende J, Lacroix A, Anderson $G$, et al. Health risks and benefits from calcium and vitamin D supplementation: Women's Health Initiative clinical trial and cohort study. Osteoporos Int. 2013;24(2):567-80.

\section{Publisher's Note}

Springer Nature remains neutral with regard to jurisdictional claims in published maps and institutional affiliations.

Ready to submit your research? Choose BMC and benefit from:

- fast, convenient online submission

- thorough peer review by experienced researchers in your field

- rapid publication on acceptance

- support for research data, including large and complex data types

- gold Open Access which fosters wider collaboration and increased citations

- maximum visibility for your research: over $100 \mathrm{M}$ website views per year

At BMC, research is always in progress.

Learn more biomedcentral.com/submissions 